\title{
Clinicopathological Implication of Insulin-like Growth Factor-II mRNA-Binding Protein 3 (IMP3) Expression in Gastric Cancer
}

\author{
DAKEUN LEE ${ }^{1}$, EUN JI YU ${ }^{1}$, IN-HYE HAM ${ }^{2,3}$ and HOON HUR ${ }^{2,3}$ \\ Departments of ${ }^{1}$ Pathology, and ${ }^{2}$ Surgery, Ajou University School of Medicine, Suwon, Republic of Korea; \\ ${ }^{3}$ Brain Korea 21 Plus Research Center for Biomedical Science, Ajou University, Suwon, Republic of Korea
}

\begin{abstract}
Background: The clinicopathological significance of oncofetal mRNA-binding protein, human insulin-like growth factor II mRNA-binding protein 3 (IMP3), in gastric carcinoma $(G C)$ is not fully understood. Materials and Methods: Tissue microarray blocks with specimens from 346 patients with GC were constructed to evaluate the clinicopathological role of IMP3 expression in GC. These results were validated with an online dataset of 876 patients from the Kaplan-Meier Plotter. Sera from 15 controls and 57 patients with $G C$ were collected in order to compare the levels of serum IMP3 between groups. Results: High expression of IMP3 was significantly associated with poor prognosis. Survival curves from the Kaplan-Meier Plotter showed that high IMP3 expression was significantly related to worse disease-free survival and overall survival. Conclusion: Tissue overexpression of IMP3 might be used as a predictor of advanced disease or lymph node metastasis, and is associated with poorer prognosis in GCs.
\end{abstract}

Currently, gastric carcinoma (GC) is the fifth most common malignancy and the third leading cause of cancer-related deaths worldwide $(1,2)$. With improved diagnostic surveillance, the proportion of patients diagnosed with earlystage disease is increasing and GC is becoming curable in many such patients. However, patients with advanced disease continue to show poor prognosis even after curative surgery and adjuvant chemotherapy $(3,4)$. In particular, the initial response rate to multi-agent chemotherapy is $50 \%$ or greater; however, nearly all patients develop resistance to

Correspondence to: Hoon Hur, MD, Ph.D., Department of Surgery, Ajou University School of Medicine, Cancer Biology Graduate Program, Ajou University Graduate School of Medicine, 164 Worldcup-ro, Yeongtong-gu, Suwon-si, Gyunggi-do 16499, Republic of Korea. Tel: +82 312195200, Fax: +82 312195575, email: hhcmc75@naver.com, hhcmc75@ajou.ac.kr

Key Words: Gastric cancer, insulin-like growth factor-II mRNAbinding protein 3 , prognosis. chemotherapy, and the median survival is extended by only up to 9-11 months with such therapy $(5,6)$. Thus, identification of new biomarkers for early detection and prediction of outcome is required to improve the management of patients with GC.

Human insulin-like growth factor (IGF)-II mRNA-binding protein 3 (IMP3, also known as IGF2BP3) is an oncofetal mRNA-binding protein (7). IMP3 binds to the 5-untranslated region of the IGF-II leader-3 mRNA as a translational activator encoding the IGF-II protein, which regulates cell proliferation (8). IMP3 is expressed in developing epithelia, myocytes, and the placenta during the early stage of human embryogenesis, but is expressed at very low or undetectable levels in normal human adult tissues (9). IMP3 overexpression has been described in many malignant tumors, with promising diagnostic utility; IMP3 expression has been shown to be associated with poor prognosis in several types of cancer, including GC, colorectal, lung, and prostatic (10-14). However, the prognostic significance of IMP3 in GC was evaluated only in a small number of patients $(13,14)$. Furthermore, although correlation between prognosis and serum IMP3 levels was reported in patients with prostate cancer, the circulating levels of IMP3 have not been investigated in patients with GC.

In the present study, we investigated the protein expression of IMP3 by immunohistochemistry (IHC) in GC tissues and assessed the serum concentration of IMP3 using enzyme-linked immunosorbent assay (ELISA). We finally evaluated the correlation of clinicopathological features and prognostic values with tissue and serum IMP3 levels in a large cohort of patients with GC after curative surgery.

\section{Materials and Methods}

Patient selection and data collection. In total, 346 patients with GC who had undergone curative surgical resection with standard lymphadenectomy from January 2005 to December 2006 at the Ajou University Hospital were enrolled in this study. Hematoxylin and eosin (H\&E) -stained sections were reviewed and appropriate histological diagnoses were made. The tumors were classified into differentiated-type (well-differentiated and moderately differentiated 
adenocarcinoma) and undifferentiated-type (poorly differentiated adenocarcinoma, signet ring cell carcinoma, and mucinous adenocarcinoma) for statistical analysis. The pathological stages were adjusted based on the seventh edition of the American Joint Committee on Cancer staging manual (15). Patients who were pathologically diagnosed with stage II or higher stages of GC were recommended treatment with adjuvant chemotherapeutic regimens including 5-fluorouracil. In addition, we planned to follow-up these patients for at least 5 years after surgery, with assessment of computed tomography, tumor markers, and gastroscopy around two to four times per year. Clinical data were retrieved from the patients' medical records. The median follow-up duration was 71 months. For external validation, an online database (http://kmplot.com/analysis) was used to determine the impact of IMP3 mRNA expression on overall (OS) and disease-free (DFS) survival. The database included microarray data from 1,065 patients with GC, with a mean follow-up period of 33 months (16).

The serum cohort consisted of 15 healthy controls and 57 patients with GC who underwent curative surgical resection with standard lymphadenectomy from January 2005 to June 2007 at the Ajou University Hospital. For patients, sera were collected at the Ajou Human Bio-Resource Bank before surgery, and then frozen at $-80^{\circ} \mathrm{C}$ until use.

This study was conducted in accordance with the ethics code of the World Medical Association (Declaration of Helsinki), and was approved by the Institutional Review Board of Ajou University Hospital (AJIRB-BMR-OBS-16-133).

Tissue microarray construction. Tissue microarray (TMA) blocks were constructed for 346 cases of gastric adenocarcinoma using a tissue array (UNITMA, Seoul, Korea). The H\&E sections of each case were reviewed by a gastrointestinal pathologist (DL) and representative areas were selected for TMA construction. Each individual case was represented by two tumor cores of $2.0 \mathrm{~mm}$ taken from the corresponding formalin-fixed, paraffin-embedded blocks.

Immunohistochemistry (IHC). Rabbit polyclonal antibody to IMP3 was purchased from the Human Protein (Atlas, Stockholm, Sweden) (diluted 1:200), and immunostaining was performed on formalinfixed, paraffin-embedded, $4-\mu \mathrm{m}$-thick tissue sections using a Ventana BenchMark XT ${ }^{\circledR}$ autoimmunostainer (Ventana Medical Systems, Tucson, AZ, USA) with a cell conditioner for $60 \mathrm{~min}$. The slides were incubated with primary antibody at $37^{\circ} \mathrm{C}$ for $32 \mathrm{~min}$, followed by standard Ventana signal amplification, counterstaining with hematoxylin for $4 \mathrm{~min}$, and staining with a bluing reagent for $4 \mathrm{~min}$. The slides were then removed from the immunostainer, mounted, and examined by light microscopy. Slides processed without the primary antibody were used as negative controls. Moderate to strong cytoplasmic staining in more than $10 \%$ of the tumor cells was classified as IMP3-high, whereas the remaining cases (including weak or negative staining) were classified as IMP3-low.

Measurement of serum IMP3 level. The serum IMP3 level was quantified using a sandwich ELISA kit from Elabscience Biotechnology Co. (Wuhan, China), according to the manufacturer's instructions [limit of detection (LOD) $=0.19 \mathrm{ng} / \mathrm{ml}$, limit of quantification $(\mathrm{LOQ})=0.57 \mathrm{ng} / \mathrm{ml}$. All samples were examined in duplicate and mean values were used for statistical analysis.

Statistical analysis. Statistical analyses were performed using SPSS for Windows (version 22.0, IBM Corp., Armonk, NY, USA). Associations between IMP3 protein expression and clinicopathological parameters were examined by Pearson's $\chi^{2}$. Serum IMP3 levels were compared by an unpaired $t$-test. OS was defined as the time between the day of surgery and the date of death. DFS was defined as the day of surgery and the date of relapse or death. OS and DFS were determined using the Kaplan-Meier method, and survival curves were compared using the log-rank test. Multivariate analyses for survival were performed using a Cox proportional hazards regression model. A $p$-value less than 0.05 was considered statistically significant. All reported $p$-values are two-sided.

\section{Results}

Patient characteristics. Among the 346 patients, 240 (69.3\%) were male and $106(30.7 \%)$ were female. Approximately half the patients (185 patients, $53.4 \%$ ) were over 60 years old (median=62 years; range $=23-85$ years). Tumors were frequently located in the lower third (184 cases, $53.1 \%$ ) of the stomach, followed by the mid-third (94 cases, 27.2\%) and the upper-third (68 cases, 19.7\%). The most common depth of invasion was T4 (134 cases, 38.7\%), and 240 cases $(69.3 \%)$ showed metastatic disease in regional lymph nodes. In total, 261 patients $(75.4 \%)$ were treated with adjuvant chemotherapy including a fluorouracil-based regimen with DNA-damaging agents such as cisplatin, oxaliplatin, and mitomycin.

Relationship between IMP3 expression and clinicopathological parameters. The normal gastric mucosa showed non-specific and faint staining for IMP3, as reported previously (15). IMP3 was expressed with moderate to strong intensity in 238 out of 346 GC samples $(68.8 \%)$, and these were therefore classified as IMP3-high, whereas 108 cases $(31.2 \%)$ were classified as IMP3-low. Representative photomicrographs of IMP3 expression in normal gastric epithelium and GC tissue are shown in Figure 1.

Overexpression of IMP3 (IMP3-high) in GC tissues was identified significantly more in specimens with large tumor size $(p<0.001)$, higher $\mathrm{T}$ stage $(p=0.001)$, higher $\mathrm{N}$ stage $(p<0.001)$, and neural/perineural invasion $(p=0.009)$ (Table I). IMP3-high status was also more frequent in cases with lymphovascular invasion $(p=0.079)$, although not reaching statistical significance. The expression status of IMP3 was not associated with other clinicopathological parameters such as age $(p=0.862)$, gender $(p=0.216)$, tumor location $(p=0.777)$, and histology $(p=0.127)$.

Prognostic significance of tissue IMP3 expression. In univariate analyses, older age ( $>60$ years), large tumor size $(>5 \mathrm{~cm})$, and undifferentiated histology were all closely associated with a worse DFS and OS. A higher T stage (T34), higher N stage (N2-3), the presence of lymphovascular invasion, and the presence of neural/perineural invasion also predicted significantly shorter DFS and OS (Table II). The expression status of IMP3 was correlated with patient 


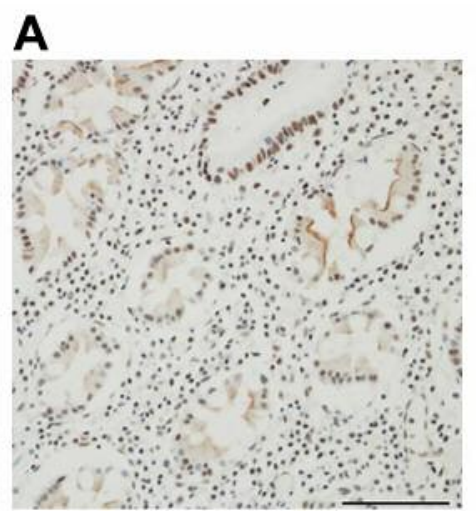

B
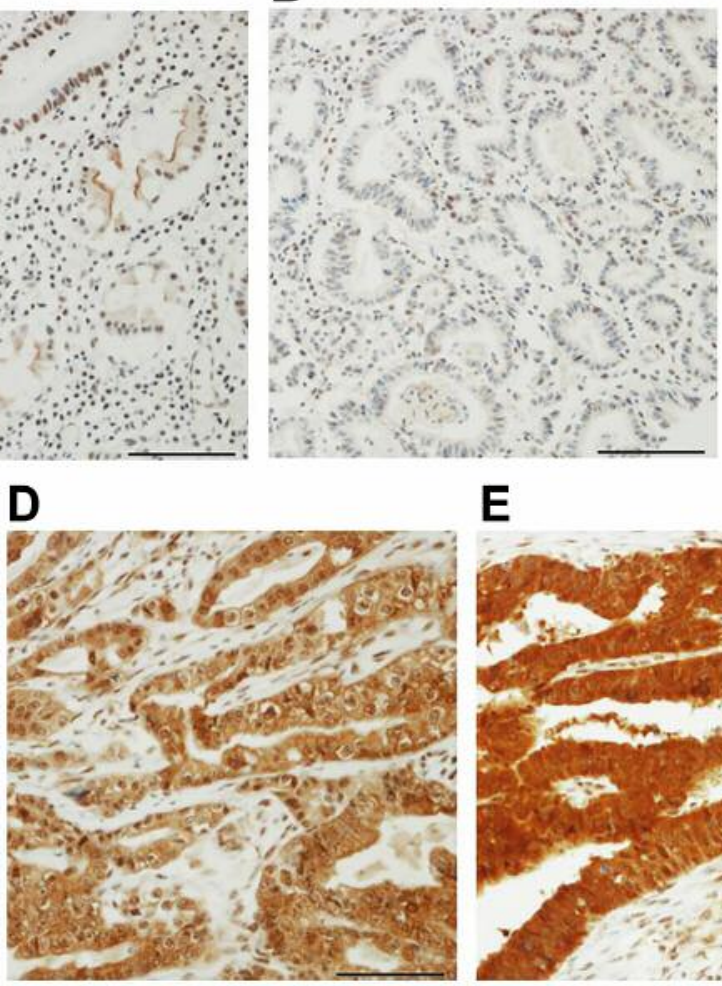

\section{C}

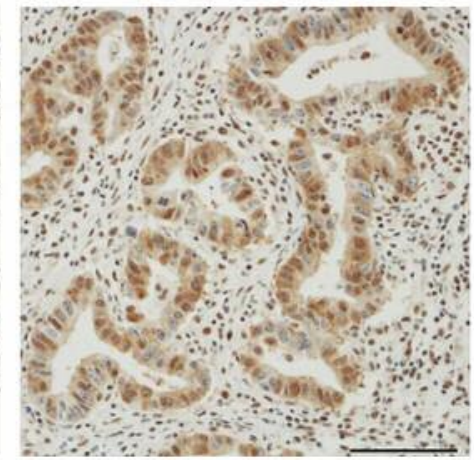

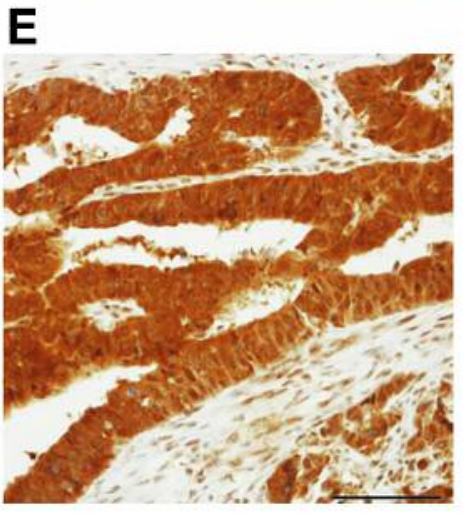

Figure 1. Representative photomicrographs of immunohistochemical expression of insulin-like growth factor-II mRNA-binding protein 3 (IMP3) showing normal gastric epithelium $(A)$, and negative $(B)$, weak $(C)$, moderate $(D)$ and strong $(E)$ staining intensity; bar=100 $\mu \mathrm{m}$.
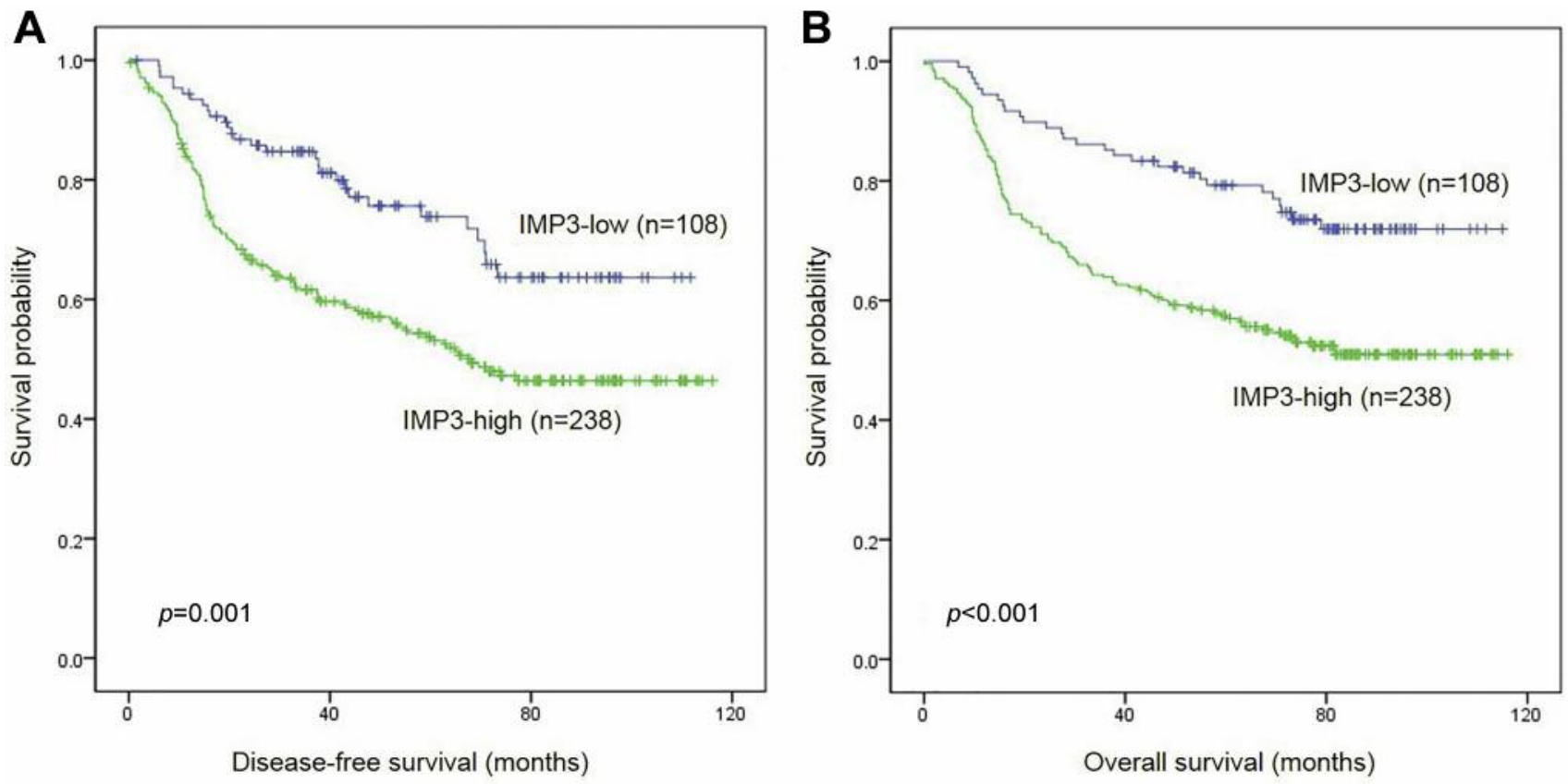

Figure 2. Kaplan-Meier curves for disease-free (A) and overall (B) survival of enrolled patients according to insulin-like growth factor-II mRNAbinding protein 3 (IMP3) expression status. 
Table I. Clinicopathological characteristics of gastric cancer patients according to human insulin-like growth factor (IGF)-II mRNA-binding protein 3 (IMP3) expression status.

\begin{tabular}{|c|c|c|c|c|}
\hline \multirow[b]{2}{*}{ Characteristic } & \multirow[b]{2}{*}{$\mathrm{n}$} & \multicolumn{2}{|c|}{$\begin{array}{l}\text { Tissue IMP3 } \\
\text { expression (\%) }\end{array}$} & \multirow[b]{2}{*}{$p$-Value } \\
\hline & & Low & High & \\
\hline Age & & & & 0.862 \\
\hline$\leq 60$ Years & 161 & $51(31.7)$ & $110(68.3)$ & \\
\hline$>60$ Years & 185 & $57(30.8)$ & $128(69.2)$ & \\
\hline Gender & & & & 0.216 \\
\hline Male & 240 & $70(29.2)$ & $170(70.8)$ & \\
\hline Female & 106 & $38(35.8)$ & $68(64.2)$ & \\
\hline Tumor size & & & & $<0.001$ \\
\hline$\leq 5 \mathrm{~cm}$ & 164 & $69(42.1)$ & $95(57.9)$ & \\
\hline$>5 \mathrm{~cm}$ & 182 & $39(21.4)$ & $143(78.6)$ & \\
\hline Tumor location & & & & 0.777 \\
\hline Upper & 68 & $20(29.4)$ & $48(70.6)$ & \\
\hline Mid & 94 & $32(34)$ & $62(66)$ & \\
\hline Lower & 184 & $56(30.4)$ & $128(69.6)$ & \\
\hline Histology & & & & 0.127 \\
\hline Well-differentiated & 37 & $15(40.5)$ & $22(59.5)$ & \\
\hline Moderately differentiated & 107 & $27(25.2)$ & $80(74.8)$ & \\
\hline Poorly differentiated & 108 & $29(26.9)$ & $79(73.1)$ & \\
\hline Signet ring cell & 78 & $31(39.7)$ & $47(60.3)$ & \\
\hline Mucinous & 16 & $6(37.5)$ & $10(62.5)$ & \\
\hline Lauren classification & & & & 0.08 \\
\hline Intestinal & 210 & $63(30)$ & $147(70)$ & \\
\hline Diffuse & 110 & $41(37.3)$ & $69(62.7)$ & \\
\hline Mixed & 26 & $4(15.4)$ & $22(84.6)$ & \\
\hline T Stage & & & & 0.001 \\
\hline $\mathrm{T} 1 \mathrm{~b}$ & 63 & $30(47.6)$ & $33(52.4)$ & \\
\hline $\mathrm{T} 2$ & 53 & $23(43.4)$ & $30(56.6)$ & \\
\hline $\mathrm{T} 3$ & 96 & $25(26)$ & $71(74)$ & \\
\hline $\mathrm{T} 4$ & 134 & $30(22.4)$ & $104(77.6)$ & \\
\hline N Stage & & & & $<0.001$ \\
\hline No & 106 & $52(49.1)$ & $54(50.9)$ & \\
\hline N1 & 69 & $17(24.6)$ & $52(75.4)$ & \\
\hline $\mathrm{N} 2$ & 60 & $13(21.7)$ & $47(78.3)$ & \\
\hline N3a & 64 & $16(25)$ & $48(75)$ & \\
\hline $\mathrm{N} 3 \mathrm{~b}$ & 47 & $10(21.3)$ & $37(78.7)$ & \\
\hline Lymphovascular invasion & & & & 0.079 \\
\hline Absent & 168 & $60(35.7)$ & $108(64.3)$ & \\
\hline Present & 178 & $48(27)$ & $130(73)$ & \\
\hline Neural/perineural invasion & & & & 0.009 \\
\hline Absent & 232 & $83(35.8)$ & $149(64.2)$ & \\
\hline Present & 114 & $25(21.9)$ & $89(78.1)$ & \\
\hline
\end{tabular}

survival, and IMP3-high cases had significantly worse mean DFS than the IMP3-low cases (68.1 vs. 85.4 months, $p=0.001$ ) (Figure 2A). This group of patients also exhibited significantly shorter mean OS (72.4 vs. 93.6 months, $p<0.001$ ) (Figure 2B). Multivariate analysis identified age, tumor size, histology, and $\mathrm{N}$ stage as significant independent prognostic factors, whereas IMP3 overexpression was not an independent prognostic factor predicting worse DFS [hazard ratio $(\mathrm{HR})=1.446, p=0.083]$ and $\mathrm{OS}(\mathrm{HR}=1.514, p=0.055)$ in patients with GC (Table III).

Independent validation. The IMP3 gene was found in the GC dataset at www.kmplot.com. The desired Affymetrix IDs for IMP3 were 203819_s_at and 216494_s_at. The survival curves for DFS were plotted with 876 patients and those for OS was created with 641 patients. Patients with high expression of IMP3 in GC had significantly worse DFS $(\mathrm{HR}=1.41-1.77)$ and $\mathrm{OS}(\mathrm{HR}=1.26-1.59)$ as compared to those with low IMP3 expression (Figure 3).

Detection of serum IMP3 in patients with GC and healthy controls. The serum cohort consisted of 15 young healthy controls (mean age $=31.6$ years, range $=26-39$ years) and 57 patients with GC (mean age $=61.4$ years, range $=33-80$ years). Unexpectedly, serum IMP3 levels were significantly higher in the controls [mean \pm standard deviation $(\mathrm{SD})=3.796 \pm 6.452$ $\mathrm{ng} / \mathrm{ml}$ ] compared to those in patients with GC $($ mean $\pm \mathrm{SD}=0.387 \pm 0.629 \mathrm{ng} / \mathrm{ml})(p<0.0001)$. The range for serum IMP3 level in controls was LOQ-25.47 ng/ml (median $=2.255 \mathrm{ng} / \mathrm{ml}$ ), whereas that in patients with $\mathrm{GC}$ was $<$ LOQ-3.228 ng/ml. We found that serum IMP3 was below the LOQ in the majority of patients with GC. There were no clinicopathological correlations associated with serum IMP3 levels in patients with GC (data not shown).

\section{Discussion}

The IGF-II mRNA binding protein family consists of IMP1, IMP2, and IMP3 (7). In the early stage of embryogenesis, IMP3 plays an important role in RNA trafficking, stabilization, cell growth, and cell migration $(7,17)$. The gene encoding the IMP3 protein is located on chromosome $7 \mathrm{p} 11.2$ (within $11 \mathrm{~cm}$ from this location) (18) and is identical to the $\mathrm{KH}$-domain-containing protein overexpressed in cancer protein (KOC) that was originally cloned from a pancreatic cancer cDNA screen (19). IMP3 is expressed at low or undetectable levels in healthy adult tissues $(7,17)$, whereas re-expression of IMP3 has been found in a number of human malignant neoplasms. In addition, IMP3 overexpression determined by IHC, has been recognized as an indicator for cancer progression and metastasis, and a predictor of poor prognosis in a variety of cancer types including GC $(10-14,20)$.

Two IHC studies have assessed the prognostic implications of tissue IMP3 expression in GC. Lin et al. identified positive IMP3 staining in 75 out of 92 cases (82\%) of GC, and that high IMP3 expression was associated with lymph node metastasis and TNM stage (14). In that study, IMP3 was an independent poor prognostic factor. Another study also used a similarly sized GC cohort (96 patients) and found positive IMP3 staining in $74 \%$ of GC samples. IMP3 expression was 
Table II. Univariate analysis for survival according to the clinicopathological features of 346 cases of gastric cancer.

\begin{tabular}{|c|c|c|c|c|}
\hline \multirow[t]{2}{*}{ Variable } & \multicolumn{2}{|c|}{ Disease-free survival } & \multicolumn{2}{|c|}{ Overall survival } \\
\hline & $\mathrm{HR}(95 \% \mathrm{CI})$ & $p$-Value & $\mathrm{HR}(95 \% \mathrm{CI})$ & $p$-Value \\
\hline Age: $>60 v s . \leq 60$ years & $1.613(1.154-2.255)$ & 0.005 & $1.508(1.076-2.114)$ & 0.017 \\
\hline Gender: male $v s$. female & $1.2(0.829-1.739)$ & 0.334 & $1.258(0.864-1.83)$ & 0.231 \\
\hline Tumor size: $>5 v s . \leq 5 \mathrm{~cm}$ & $3.135(2.176-4.518)$ & $<0.001$ & $3.412(2.349-4.956)$ & $<0.001$ \\
\hline Histology: undifferentiated $v s$. differentiated & $1.686(1.19-2.389)$ & 0.003 & $1.739(1.222-2.473)$ & 0.002 \\
\hline Lauren: diffuse/mixed $v s$. intestinal & $1.378(0.993-1.913)$ & 0.055 & $1.378(0.989-1.919)$ & 0.058 \\
\hline T Stage: $\mathrm{T} 3 / 4$ s. $\mathrm{T} 1 \mathrm{~b} / \mathrm{T} 2$ & $3.132(2.004-4.893)$ & $<0.001$ & $3.376(2.158-5.282)$ & $<0.001$ \\
\hline N Stage: N2/3 vs. N0/N1 & $4.531(3.092-6.638)$ & $<0.001$ & $5.006(3.383-7.408)$ & $<0.001$ \\
\hline Lymphovascular invasion: present $v s$. absent & $2.019(1.437-2.837)$ & $<0.001$ & $2.155(1.525-3.045)$ & $<0.001$ \\
\hline Neural/perineural invasion: present $v s$. absent & $1.52(1.091-2.117)$ & 0.013 & $1.625(1.167-2.274)$ & 0.005 \\
\hline IMP3: high vs. low & $2.03(1.35-3.051)$ & 0.001 & $2.196(1.452-3.323)$ & $<0.001$ \\
\hline
\end{tabular}

HR, Hazard ratio; CI, confidence interval; IMP3, insulin-like growth factor-II mRNA-binding protein 3. Differentiated includes well- and moderately differentiated adenocarcinomas. Undifferentiated includes poorly differentiated, signet ring cell, and mucinous adenocarcinomas. Significant differences are shown in bold.

Table III. Multivariate analysis by the Cox proportional hazard regression model for disease-free and overall survival in patients with gastric cancer.

\begin{tabular}{|c|c|c|c|c|}
\hline \multirow[t]{2}{*}{ Variable } & \multicolumn{2}{|c|}{ Disease-free survival } & \multicolumn{2}{|c|}{ Overall survival } \\
\hline & $\mathrm{HR}(95 \% \mathrm{CI})$ & $p$-Value & $\operatorname{HR}(95 \% \mathrm{CI})$ & $p$-Value \\
\hline Age: $>60 v s . \leq 60$ years & $1.839(1.297-2.607)$ & 0.001 & $1.708(1.205-2.420)$ & 0.003 \\
\hline Tumor size: $>5 v s . \leq 5 \mathrm{~cm}$ & $2.191(1.467-3.271)$ & $<0.001$ & $2.300(1.530-3.457)$ & $<0.001$ \\
\hline Histology: undifferentiated $v s$. differentiated & $1.511(1.053-2.169)$ & 0.025 & $1.521(1.057-2.190)$ & 0.024 \\
\hline T Stage: T3/4 vs. T1b/T2 & $1.305(0.771-2.211)$ & 0.322 & $1.319(0.776-2.242)$ & 0.307 \\
\hline N Stage: N2/3 vs. N0/N1 & $3.576(2.320-5.511)$ & $<0.001$ & $3.856(2.480-5.995)$ & $<0.001$ \\
\hline Lymphovascular invasion: present $v s$. absent & $1.059(0.732-1.533)$ & 0.760 & $1.117(0.771-1.619)$ & 0.557 \\
\hline Neural/perineural invasion: present $v s$. absent & $0.892(0.624-1.277)$ & 0.533 & $0.870(0.606-1.250)$ & 0.557 \\
\hline IMP3: high vs. low & $1.446(0.953-2.195)$ & 0.083 & $1.514(0.991-2.315)$ & 0.055 \\
\hline
\end{tabular}

HR, Hazard ratio; CI, confidence interval; IMP3, insulin-like growth factor-II mRNA-binding protein 3. Differentiated includes well and moderately differentiated adenocarcinomas. Undifferentiated includes poorly differentiated, signet ring cell, and mucinous adenocarcinomas. Significant differences are shown in bold.

not correlated with any clinicopathological parameters, but tissue IMP3 expression correlated significantly with worse recurrence-free survival and OS. IMP3 was a significant independent prognostic factor only for DFS (13). We investigated tissue IMP3 expression in a large cohort of patients with GC (346 patients), and found high IMP3 expression in 238 out of 346 GC cases $(68.8 \%)$, which is similar to that observed in previous studies $(13,14)$. In the present study, we demonstrated that IMP3 overexpression was significantly correlated with large tumor size, higher $\mathrm{T}$ stages, higher $\mathrm{N}$ stages, and the presence of neural/perineural invasion. Tissue IMP3 expression was associated with worse DFS and OS. Moreover, analysis of an online public database from the Kaplan-Meier Plotter for the mRNA expression of IMP3 also supported the present results of IHC for IMP3 protein expression in GC. However, in contrast to these studies, IMP3 was not found to be an independent prognostic indicator in our study, probably due to its tight correlation with well-established powerful prognostic factors such as $\mathrm{T}$ and $\mathrm{N}$ stage. In this context, high IMP3 expression in biopsy samples can be used as a predictor of advanced disease or lymph node metastasis in GC. In fact, Wei et al. demonstrated that high IMP3 expression in biopsy specimens of colorectal cancer predicted lymph node metastasis and TNM stage (21). In renal cell carcinomas, IMP3 was greatly increased, not only in metastatic tumors but also in a subset of primary tumors that were likely to develop metastases (20).

Recently, a few attempts have been made to identify IMP3 in various human samples. Okada et al. assessed IMP3 mRNA expression by reverse transcription polymerase chain reaction 

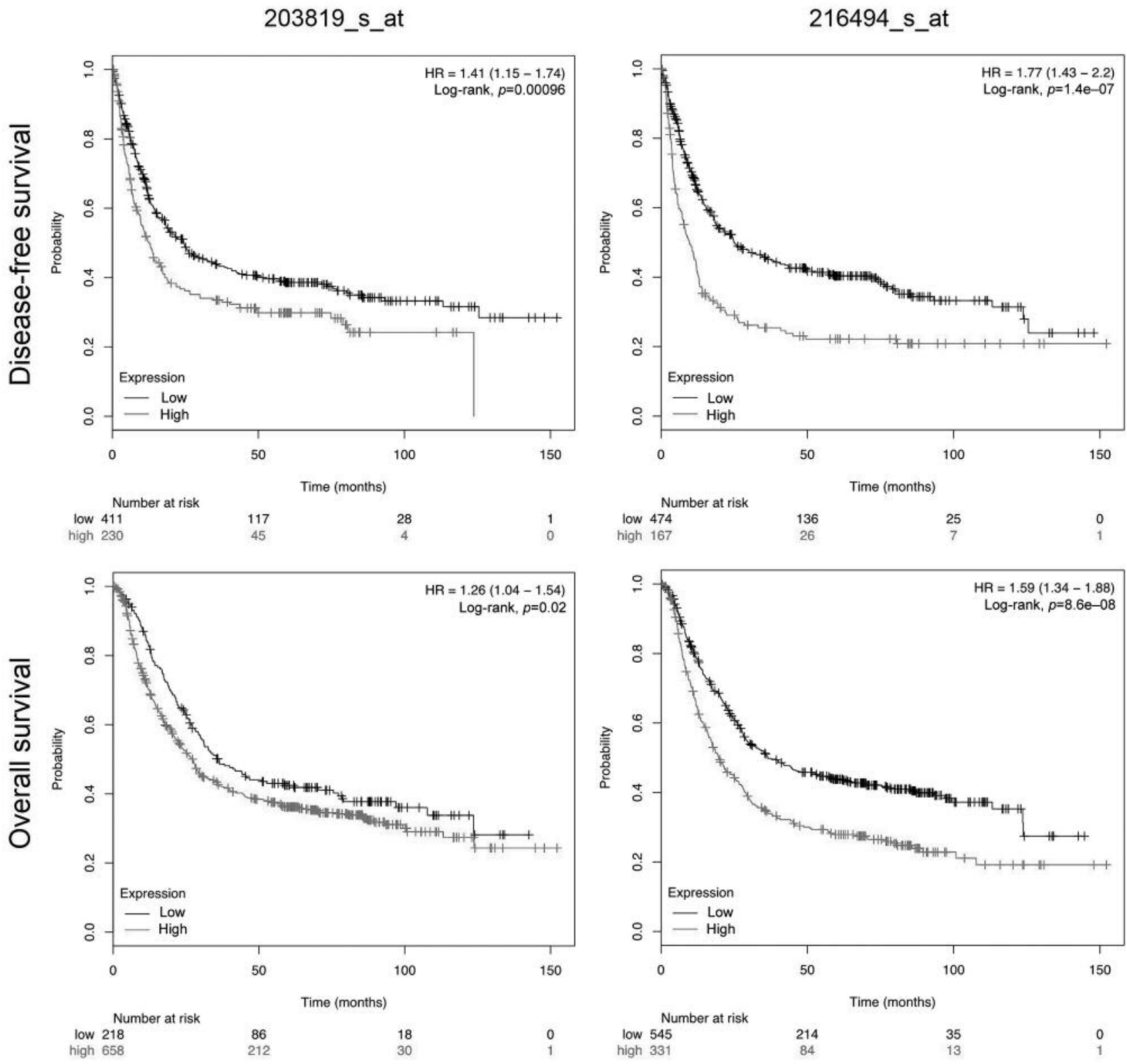

Figure 3. Prognostic value of insulin-like growth factor-II mRNA-binding protein 3 (IMP3) mRNA level in patients with gastric cancer. Diseasefree (A) and overall (B) survival rate for gastric cancer datasets 203819_s_at and 216494_s_at. Data were analyzed using Kaplan-Meier Plotter (http://www.kmplot.com). HR: Hazard ratio; confidence interval, confidence interval.

in 36 cytologically negative peritoneal lavage samples and found eight cases (28\%) of IMP3 expression, which was correlated with worse OS (13). Szarvas et al. found that serum IMP3 concentrations were significantly higher in patients with prostate cancer compared to those with benign prostate hyperplasia and controls (11). A high serum IMP3 level was independently associated with poor cancer-specific survival (11). Since the circulating IMP3 level has never been investigated in patients with GC as far as we are aware, we assessed the serum IMP3 level using ELISA to determine its diagnostic or prognostic role in GC. Unexpectedly, the serum IMP3 level was very low in patients with GC, and practically, IMP3 was not detected in the majority of these patients, even in those with advanced disease. In contrast, the serum IMP3 concentration was significantly higher in control samples. Considering the role of IMP3 in developing tissues, we suppose that this discrepancy might be attributed to the younger age of the controls compared to the patients. In addition, we confirmed 
that serum IMP3 is practically undetectable in patients with GC, and thus has no diagnostic or prognostic value. On the other hand, a previous study reported a high serum IMP3 level in patients with prostate cancer (mean $=20.7 \mathrm{ng} / \mathrm{ml}$, range $=1.3$ $147.2 \mathrm{ng} / \mathrm{ml}$ ), suggesting that a high serum IMP3 level might be a consequence of disturbed normal tissue structure rather than of secretion by tumor cells (11).

Only a few studies have previously investigated the role of IMP3 in tumorigenesis or tumor progression. IMP3 was reported to promote cell proliferation, adhesion, and invadopodia formation during cancer progression (22). Knockout of IMP3 resulted in reduced migration and invasion in cervical and lung cancer cell lines (10, 23). Recently, Samanta et al. demonstrated that IMP3 contributes to self-renewal and tumor initiation, which are properties associated with cancer stem cells, by regulating Slug expression in triple-negative breast cancer (24). However, the functional role of IMP3 in GC remains poorly understood and needs to be further investigated.

In conclusion, IMP3 is a promising tumor biomarker in GC, since its tissue expression was found to be well correlated with large tumor size and higher $\mathrm{T}$ and $\mathrm{N}$ stages. Thus, it might be used as a predictor of advanced disease or lymph node metastasis in GC. Tissue IMP3 overexpression was associated with poorer prognosis, but only in univariate analysis. The serum IMP3 level has no diagnostic utility because IMP3 was barely detected in patients with GC. Further studies are required to elucidate the molecular mechanisms and pathways by which IMP3 affects the biological phenotype of GC cells.

\section{Conflicts of Interest}

The Authors declare that there are no conflicts of interest.

\section{Acknowledgements}

The biological specimens for this study were provided by the Ajou Human Bio-Resource Bank (AHBB), a member of the National Biobank of Korea, which is supported by the Ministry of Health and Welfare. This research was supported by the Basic Science Research Program through the National Research Foundation of Korea (NRF), funded by the Ministry of Education (2014R1A1A1007905 \& 2014R1A1A2057390). This research was also supported by the 2014 New Faculty Research Fund of Ajou University School of Medicine.

\section{References}

1 Ferlay J, Soerjomataram I, Dikshit R, Eser S, Mathers C, Rebelo M, Parkin DM, Forman D and Bray F: Cancer incidence and mortality worldwide: sources, methods and major patterns in GLOBOCAN 2012. Int J Cancer 136: E359-386, 2015.

2 Peleteiro B, Severo M, La Vecchia C and Lunet N: Model-based patterns in stomach cancer mortality worldwide. Eur J Cancer Prev 23: 524-531, 2014.
3 Bang YJ, Van Cutsem E, Feyereislova A, Chung HC, Shen L, Sawaki A, Lordick F, Ohtsu A, Omuro Y, Satoh T, Aprile G, Kulikov E, Hill J, Lehle M, Ruschoff J, Kang YK and To GATI: Trastuzumab in combination with chemotherapy versus chemotherapy alone for treatment of HER2-positive advanced gastric or gastro-oesophageal junction cancer (ToGA): a phase 3, openlabel, randomised controlled trial. Lancet 376: 687-697, 2010.

4 Lee J, Lim do H, Kim S, Park SH, Park JO, Park YS, Lim HY, Choi MG, Sohn TS, Noh JH, Bae JM, Ahn YC, Sohn I, Jung SH, Park CK, Kim KM and Kang WK: Phase III trial comparing capecitabine plus cisplatin versus capecitabine plus cisplatin with concurrent capecitabine radiotherapy in completely resected gastric cancer with D2 lymph node dissection: the ARTIST trial. J Clin Oncol 30: 268-273, 2012.

5 Cunningham D, Starling N, Rao S, Iveson T, Nicolson M, Coxon F, Middleton G, Daniel F, Oates J, Norman AR and Upper Gastrointestinal Clinical Studies Group of the National Cancer Research Institute of the United K: Capecitabine and oxaliplatin for advanced esophagogastric cancer. N Engl J Med 358: 36-46, 2008.

6 Cervantes A, Roda D, Tarazona N, Rosello S and Perez-Fidalgo JA: Current questions for the treatment of advanced gastric cancer. Cancer Treat Rev 39: 60-67, 2013.

7 Nielsen J, Christiansen J, Lykke-Andersen J, Johnsen AH, Wewer UM and Nielsen FC: A family of insulin-like growth factor II mRNA-binding proteins represses translation in late development. Mol Cell Biol 19: 1262-1270, 1999.

8 Liao B, Hu Y and Brewer G: RNA-binding protein insulin-like growth factor mRNA-binding protein 3 (IMP-3) promotes cell survival via insulin-like growth factor II signaling after ionizing radiation. J Biol Chem 286: 31145-31152, 2011.

9 Findeis-Hosey $\mathrm{JJ}$ and $\mathrm{Xu} \mathrm{H}$ : The use of insulin like-growth factor II messenger RNA binding protein-3 in diagnostic pathology. Hum Pathol 42: 303-314, 2011.

10 Yan J, Wei Q, Jian W, Qiu B, Wen J, Liu J, Fu B, Zhou X and Zhao T: IMP3 Predicts invasion and prognosis in human lung adenocarcinoma. Lung 194: 137-146, 2016.

11 Szarvas T, Tschirdewahn S, Niedworok C, Kramer G, Sevcenco S, Reis H, Shariat SF, Rubben H and vom Dorp F: Prognostic value of tissue and circulating levels of IMP3 in prostate cancer. Int J Cancer 135: 1596-1604, 2014.

12 Lochhead P, Imamura Y, Morikawa T, Kuchiba A, Yamauchi M, Liao X, Qian ZR, Nishihara R, Wu K, Meyerhardt JA, Fuchs CS and Ogino $\mathrm{S}$ : Insulin-like growth factor 2 messenger RNA binding protein 3 (IGF2BP3) is a marker of unfavourable prognosis in colorectal cancer. Eur J Cancer 48: 3405-3413, 2012.

13 Okada K, Fujiwara Y, Nakamura Y, Takiguchi S, Nakajima K, Miyata H, Yamasaki M, Kurokawa Y, Takahashi T, Mori M and Doki Y: Oncofetal protein, IMP-3, a potential marker for prediction of postoperative peritoneal dissemination in gastric adenocarcinoma. J Surg Oncol 105: 780-785, 2012.

14 Wang L, Li HG, Xia ZS, Lu J and Peng TS: IMP3 is a novel biomarker to predict metastasis and prognosis of gastric adenocarcinoma: a retrospective study. Chin Med J (Engl) 123: 3554-3558, 2010.

15 Washington K: 7th edition of the AJCC cancer staging manual: stomach. Ann Surg Oncol 17: 3077-3079, 2010.

16 Szasz AM, Lanczky A, Nagy A, Forster S, Hark K, Green JE, Boussioutas A, Busuttil R, Szabo A and Gyorffy B: Cross- 
validation of survival associated biomarkers in gastric cancer using transcriptomic data of 1,065 patients. Oncotarget DOI: 10.18632/oncotarget.10337, 2016.

17 Mueller-Pillasch F, Pohl B, Wilda M, Lacher U, Beil M, Wallrapp C, Hameister H, Knochel W, Adler G and Gress TM: Expression of the highly conserved RNA binding protein KOC in embryogenesis. Mech Dev 88: 95-99, 1999.

18 Monk D, Bentley L, Beechey C, Hitchins M, Peters J, Preece MA, Stanier P and Moore GE: Characterisation of the growth regulating gene IMP3, a candidate for Silver-Russell syndrome. J Med Genet 39: 575-581, 2002.

19 Mueller-Pillasch F, Lacher U, Wallrapp C, Micha A, Zimmerhackl F, Hameister H, Varga G, Friess H, Buchler M, Beger HG, Vila MR, Adler G and Gress TM: Cloning of a gene highly overexpressed in cancer coding for a novel KH-domain containing protein. Oncogene 14: 2729-2733, 1997.

20 Jiang Z, Chu PG, Woda BA, Rock KL, Liu Q, Hsieh CC, Li C, Chen W, Duan HO, McDougal S and Wu CL: Analysis of RNAbinding protein IMP3 to predict metastasis and prognosis of renal-cell carcinoma: a retrospective study. Lancet Oncol 7: 556$564,2006$.

21 Wei Q, Huang X, Fu B, Liu J, Zhong L, Yang Q and Zhao T: IMP3 expression in biopsy specimens of colorectal cancer predicts lymph node metastasis and TNM stage. Int J Clin Exp Pathol 8: 11024-11032, 2015.
22 Vikesaa J, Hansen TV, Jonson L, Borup R, Wewer UM, Christiansen J and Nielsen FC: RNA-binding IMPs promote cell adhesion and invadopodia formation. EMBO J 25: 1456-1468, 2006.

23 Lu D, Yang X, Jiang NY, Woda BA, Liu Q, Dresser K, Mercurio AM, Rock KL and Jiang Z: IMP3, a new biomarker to predict progression of cervical intraepithelial neoplasia into invasive cancer. Am J Surg Pathol 35: 1638-1645, 2011.

24 Samanta S, Sun H, Goel HL, Pursell B, Chang C, Khan A, Greiner DL, Cao S, Lim E, Shultz LD and Mercurio AM: IMP3 promotes stem-like properties in triple-negative breast cancer by regulating SLUG. Oncogene 35: 1111-1121, 2016.
Received November 9, 2016

Revised November 28, 2016

Accepted November 29, 2016 